\title{
Transgenic citrus plants expressing the citrus tristeza virus p23 protein exhibit viral-like symptoms
}

\author{
RIADH GHORBEL ${ }^{1}+$, CARMELO LÓPEZ ${ }^{2}+$, CARMEN FAGOAGA ${ }^{1}$, PEDRO MORENO ${ }^{1}$, \\ LUIS NAVARRO1, RICARDO FLORES ${ }^{2}$ AND LEANDRO PEÑA ${ }^{1}$ ** \\ 1 Instituto Valenciano de Investigaciones Agrarias (IVIA), Apdo. Oficial, Moncada 46113, Valencia, Spain; ${ }^{2}$ Instituto de Biología Molecular y Celular de Plantas \\ (UPV-CSIC), Universidad Politécnica de Valencia, Avenida de los Naranjos, Valencia 46022, Spain
}

\section{SUMMARY}

The $23 \mathrm{kDa}$ protein (p23) coded by the 3'-terminal gene of Citrus tristeza virus (CTV), a member of the genus Closterovirus with the largest genome among plant RNA viruses, is an RNA-binding protein that contains a motif rich in cysteine and histidine residues in the core of a putative zinc-finger domain. On this basis, a regulatory role for CTV replication or gene expression has been suggested for p23. To explore whether over-expression of this protein in transgenic plants could affect the normal CTV infection process, transgenic Mexican lime plants were generated carrying the p23 transgene, or a truncated version thereof, under the control of the cauliflower mosaic virus (CaMV) 35 s promoter. Constitutive expression of p23 induced phenotypic aberrations that resembled symptoms incited by CTV in non-transgenic lime plants, whereas transgenic plants expressing the p23 truncated version were normal. The onset of CTV-like symptoms in p23transgenic plants was associated with the expression of p23, and its accumulation level paralleled the intensity of the symptoms. This demonstrates that p23 is involved in symptom development and that it most likely plays a key role in CTV pathogenesis. This is the first case in which a protein encoded by a woody plantinfecting RNA virus has been identified as being directly involved in pathogenesis in its natural host. This finding also delimits a small region of the large CTV genome for the future mapping of specific pathogenic determinants.

\section{INTRODUCTION}

Citrus tristeza virus (CTV), a member of the genus Closterovirus, is the causal agent of one of the most economically important diseases of citrus plants. CTV is readily transmitted by grafting using infected buds and is spread locally by several aphid species

*Correspondence: E-mail: Ipenya@ivia.es

†The two first authors contributed equally to this work. in a semipersistent mode; CTV is also mechanically transmissible, but with low efficiency (Bar-Joseph et al., 1989). In nature, CTV is restricted to citrus species. CTV virions occur in phloem-associated tissues as flexuous filaments of $2000 \times 10-12 \mathrm{~nm}$ in size, with two capsid proteins of 25 (Sekiya et al., 1991) and 27 kDa (Pappu et al., 1994), coating $95 \%$ and $5 \%$ of the particle length, respectively (Febres et al., 1996). The genome is a single-stranded, positive-sense RNA molecule of 19 226-19 296 nucleotides, whose size is isolate-dependent. The genome contains 12 open reading frames (ORFs) that potentially encode at least 17 protein products with flanking untranslated regions (UTRs) (Karasev et al., 1995; Mawassi et al., 1996; Vives et al., 1999; Yang et al., 1999). The 5 '-proximal ORF 1a encodes a $349 \mathrm{kDa}$ polyprotein containing two papain-like protease domains, plus methyltransferase-like and helicase-like domains. ORF $1 \mathrm{~b}$ encodes a putative RNA-dependent RNA polymerase which is thought to be expressed by $a+1$ frameshift mechanism (Karasev et al., 1995). The 10 ORFs located in the 3' portion of the genome are expressed through a set of 3' co-terminal subgenomic (sg) mRNAs (Hilf et al., 1995). These include genes encoding the minor and the major coat proteins of 27 and $25 \mathrm{kDa}$, respectively, a small hydrophobic protein of $6 \mathrm{kDa}$, a $65 \mathrm{kDa}$ homologue of the HSP70 heat-shock proteins which likely mediates cell-to-cell movement by analogy with its beet yellow closterovirus (BYV) homologue (Peremyslov et al., 1999), and several other proteins of 33,61, 18, 13, 20 and $23 \mathrm{kDa}$ with unknown functions (Karasev et al., 1995; Pappu et al., 1994).

The ORF encoding the $23 \mathrm{kDa}$ protein, hereafter referred to as p23, is adjacent to the 3' UTR of the CTV RNA and the corresponding gene has no homologue in other closteroviruses. In infected plants, p23 accumulates at moderate levels compared to other viral proteins (Pappu et al., 1997), but p23 sgRNA is the second most abundant viral mRNA in infected tissues or protoplasts (Hilf et al., 1995; Navas-Castillo et al., 1997). Furthermore, p23 sgRNA accumulates earlier than the other sgRNAs in infected protoplasts, suggesting an involvement of the p23 protein in an early step of RNA replication or transcription (Navas-Castillo et al., 1997). Additionally, Dolja et al. (1994) showed the presence of a cluster of positively charged amino acid residues in p23, and 
López et al. (1998) further characterized this conserved region which is rich in cysteine and histidine residues in the core of a putative zinc-finger domain. All these results suggest a regulatory function for p23, a view that is further supported by the finding that in vitro, p23 binds RNA in a sequence nonspecific manner, and that mutations affecting the cysteine and histidine residues increase the dissociation constant of the p23-RNA complex (López et al., 2000).

Several strategies have been used to engineer plant resistance to viral pathogens (Baulcombe, 1996). Most are based on the concept of pathogen-derived resistance (Sanford and Johnston, 1985), which proposes that the introduction and expression in plants of viral sequences could interfere with the life cycle of the same or a closely related challenging virus, thus providing resistance to infection. Considering the potential regulatory role of CTV p23, over-expression of this protein in transgenic plants could be an effective means of disrupting the normal CTV infectious process. For this purpose, we obtained transgenic citrus plants that were constitutively expressing p23 but, surprisingly, these transgenic plants displayed CTV-like symptoms after being transferred to a greenhouse. Therefore, our interest was redirected to an investigation of the involvement of p23 in CTV pathogenesis.

\section{RESULTS}

\section{p23-transgenic Mexican limes express CTV-like symptoms}

Mexican lime (Citrus aurantifolia (Christm) Swing.) was selected for genetic transformation because it is very sensitive to CTV and shows symptoms, such as vein clearing, leaf cupping, stunting and stem pitting, with most isolates of this virus (Roistacher, 1991). The transformation vector was prepared by cloning the $p 23$ gene into the binary plasmid pBin19-sgfp under the doubly enhanced cauliflower mosaic virus (CaMV) 355 promoter and the nopaline synthase terminator (nos-ter). This expression cassette was flanked by the selectable neomycin phosphotransferase II gene (nptII), between the nos promoter (nos-pro) and the nos-ter, and by the reporter gene of the green fluorescent protein $(g f p)$ between the 355 promoter and the nos-ter (Fig. 1). The transformation of internodal stem segments from lime seedlings was mediated by Agrobacterium tumefaciens (Ghorbel et al., 1999). Fifty independent transformants were obtained in three different transformation experiments. Expression of the green fluorescent protein (GFP),

(a)

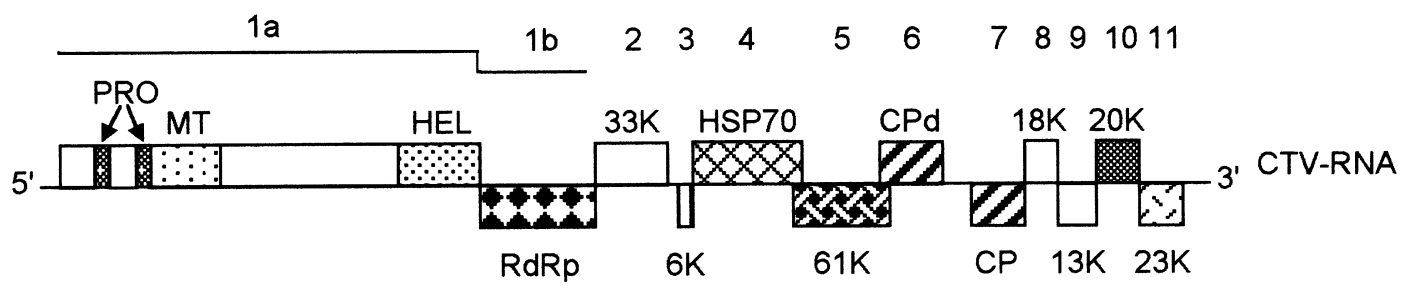

(b)

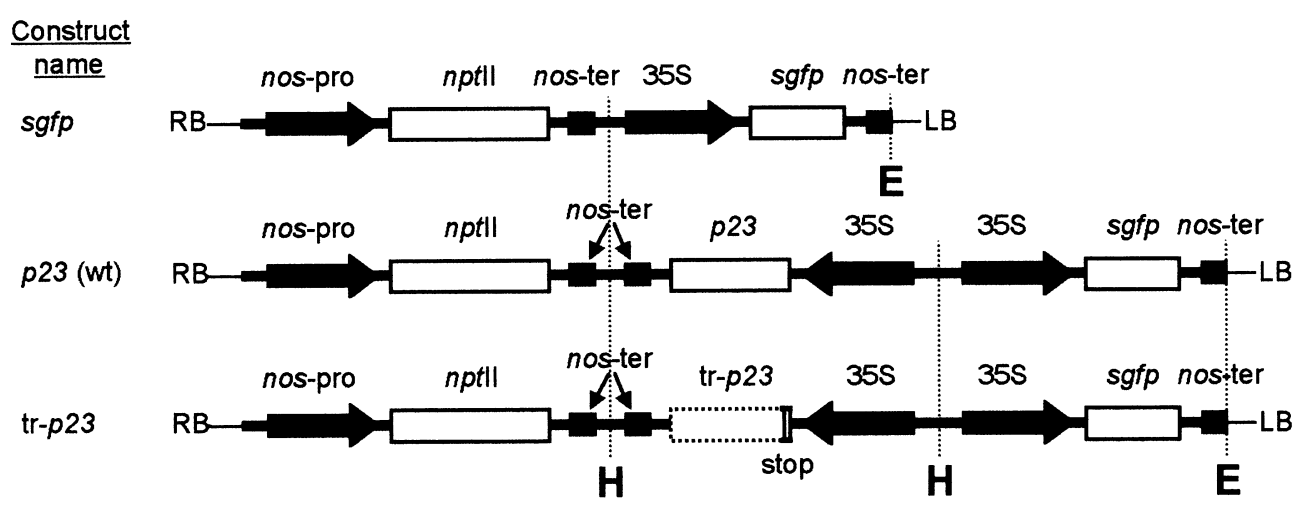

Fig. 1 Schematic representation of the CTV genome and gene constructs. (a) Distribution of open reading frames in the genomic CTV RNA according to Karasev et al. (1995). The 5' ORFs 1a and 1b produce a fusion protein with two papain-like protease (PRO), plus methyltransferase (MT), helicase (HEL) and RNA-dependent RNA polymerase (RdRp) domains. The 10 ORFs of the $3^{\prime}$ half of the genome encode a $6 \mathrm{kDa}$ hydrophobic protein, a $65 \mathrm{kDa}$ homologue of the HSP70 heat-shock proteins, the $25 \mathrm{kDa}$ major coat protein (CP) and its $27 \mathrm{kDa}$ divergent copy (CPd), and other proteins are of 33, 61, 18, 13, 20 and $23 \mathrm{kDa}$. (b) Diagram of the T-DNA from the binary vector $\mathrm{pBin} 19$-sgfp and constructs designed to express both the wild-type (wt) and truncated (tr) $p 23$ genes controlled by the doubly enhanced cauliflower mosaic virus (CaMV) 355 promoter and the nopaline synthase terminator (nos-ter). The p23 and tr-p23 cassettes are flanked by the neomycin phosphotransferase II gene (npt/I) between the nos promoter (nos-pro) and the nos-ter, and by the green fluorescent protein gene (sgfp) between the 355 promoter and the nos-ter. Hind III and EcoRI restriction sites are indicated by $\mathrm{H}$ and $\mathrm{E}$, respectively. 


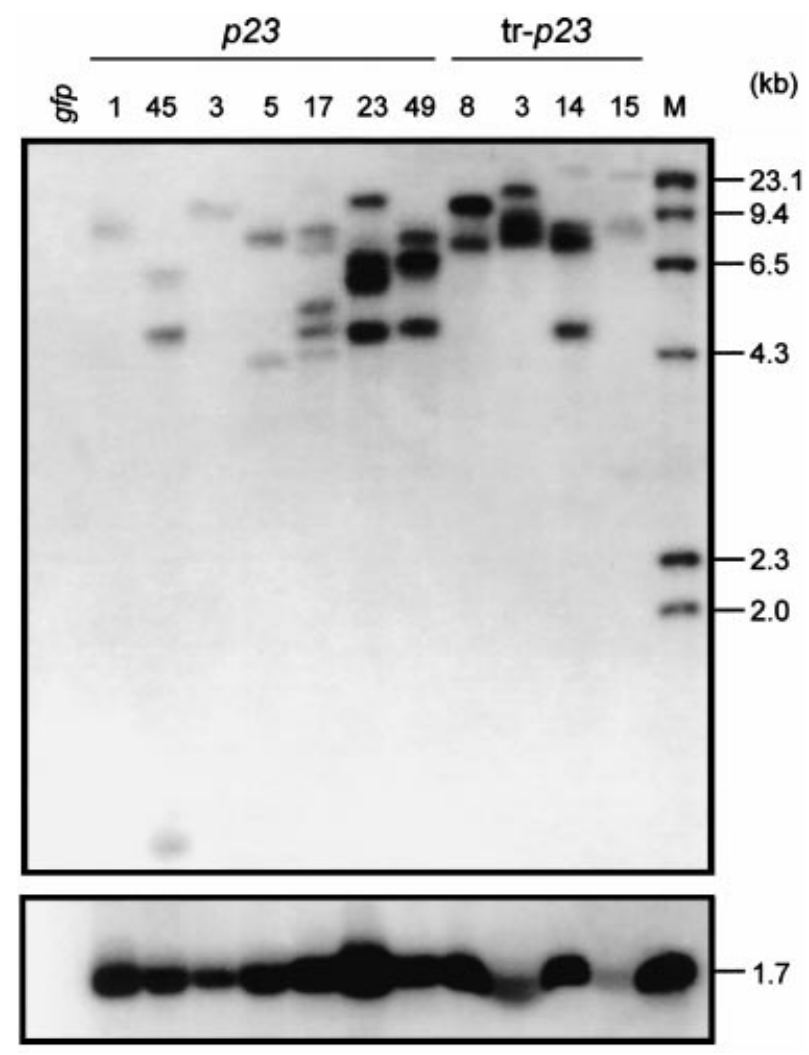

Fig. 2 Southern blot analysis of lime plants transformed with the $p 23$ gene (lanes 1, 45, 3, 5, 17, 23 and 49), with a truncated version thereof, tr-p23 (lanes 8, 3, 14 and 15), or with the vector pBin19-sgfp (lane gfp). DNA was digested with EcoRI, which cuts the T-DNA once near the left border or with HindIII, which excises the expression cassette (see Fig. 1). The size of DNA markers (lane M) are indicated at the right. Membranes were probed with a digoxigenin-labelled fragment of the $p 23$ coding region.

monitored under blue light, was observed in all the transformants. Integration of the $p 23$ transgene in all these plants was confirmed by PCR amplification of a product of the expected size (630 bp) (data not shown), and Southern blotting analysis revealed a number of copies between 1 and 5 (Fig. 2). In a parallel control experiment using the plasmid pBin19-sgfp, 10 transformants harbouring only the $n p t / l$ and $g f p$ genes were obtained. During the in vitro culture process, transgenic plants containing the $p 23$ gene were visually normal and indistinguishable from controls carrying only the marker genes.

The 60 transgenic plantlets were side-grafted on vigorous Rough lemon ( $C$. jambhiri Lush) seedlings in the greenhouse. One month later, all grafts from the transgenic controls had sprouted, whereas 16 of the $p 23$-containing transgenic grafts never sprouted. These grafts progressively showed chlorotic leaf spots and stem necrosis (Fig. 3a), and died within a few weeks or months (Fig. 3b). The rest of the $p 23$-containing grafts sprouted later than the controls and displayed severe vein clearing similar to that incited by CTV in both young and mature leaves; young leaves also developed chlorotic pinpoints (Fig. 3c). Six months after being transferred to the greenhouse, most plants exhibited leaf cupping and stem pitting (Fig. 3d). In the following growth, symptoms appeared again with variable intensity depending on the lines. These included leaf epinasty (Fig. 3e), apical necrosis (Fig. 3f), and growth interruption (Fig. 3g) or stunting (Fig. 3h) in the most severe cases. In general, the phenotype of the p23-containing transgenic plants strongly resembled the symptoms of non-transgenic Mexican lime inoculated with CTV, although vein clearing was less prominent in the latter (Fig. 3i). The aberrant phenotype observed in p23-containing transgenic plants could not be attributed to somaclonal variation or to epigenetic effects of the transformation/regeneration process, because none of the transgenic control lines displayed these alterations. To corroborate that CTV-like symptoms were not caused by an accidental CTV infection, all transgenic lines were analysed by ELISA using monoclonal antibodies 3DF1 and 3CA5 against the CTV coat protein (Vela et al., 1986), with a negative reaction in all cases (data not shown).

CTV-like symptoms usually developed in the first growth of the transgenic grafts, approximately 2 months after side grafting on the Rough lemon rootstock. Similar results were observed when buds of the transgenic plants were propagated on the less vigorous citrus rootstocks sour orange ( $C$. aurantium $\mathrm{L}$.) and Carrizo citrange (C. sinensis (L.) Osb. X Poncirus trifoliata (L.) Raf.). Phenotypic aberrations were particularly conspicuous in growing flushes, similar to that occurring with symptom development in a CTVinfected Mexican lime (Roistacher, 1991). Also, by analogy with CTV infection, stem pitting in transgenic plants was a late phenotypic effect that became evident only six months after grafting.

\section{p23 protein is required for expression of CTV-like symptoms in the transgenic Mexican lime}

To examine whether the CTV-like symptoms resulted from accumulation of the $p 23$ transcript itself or from its translation product, a modified p23 truncation construct (tr-p23) was prepared containing a frameshift mutation in the p23 ORF. This was produced by a deletion of two nucleotides that generated a stop codon after amino acid residue 14 of p23.

A second set of transgenic Mexican limes was obtained with the tr-p23 construct, using the wild-type $p 23$ gene construct as an internal control. Integration of the tr-p23 transgene was also confirmed by PCR amplification (data not shown), and Southern blot analysis revealed a number of copies between 1 and 4 (Fig. 2). As in the previous experiment, transgenic plants carrying the wildtype $p 23$ construct displayed CTV-like symptoms, with a proportion of the plants showing stem necrosis and collapse. However, all of the transgenic lines carrying the tr-p23 construct grew normally and exhibited normal phenotypes (data not shown). In Northern blot analysis with a p23-specific probe, the visually normal tr-p23 transgenic plants expressed levels of the mutated p23 transcript comparable to or higher than those found in the 

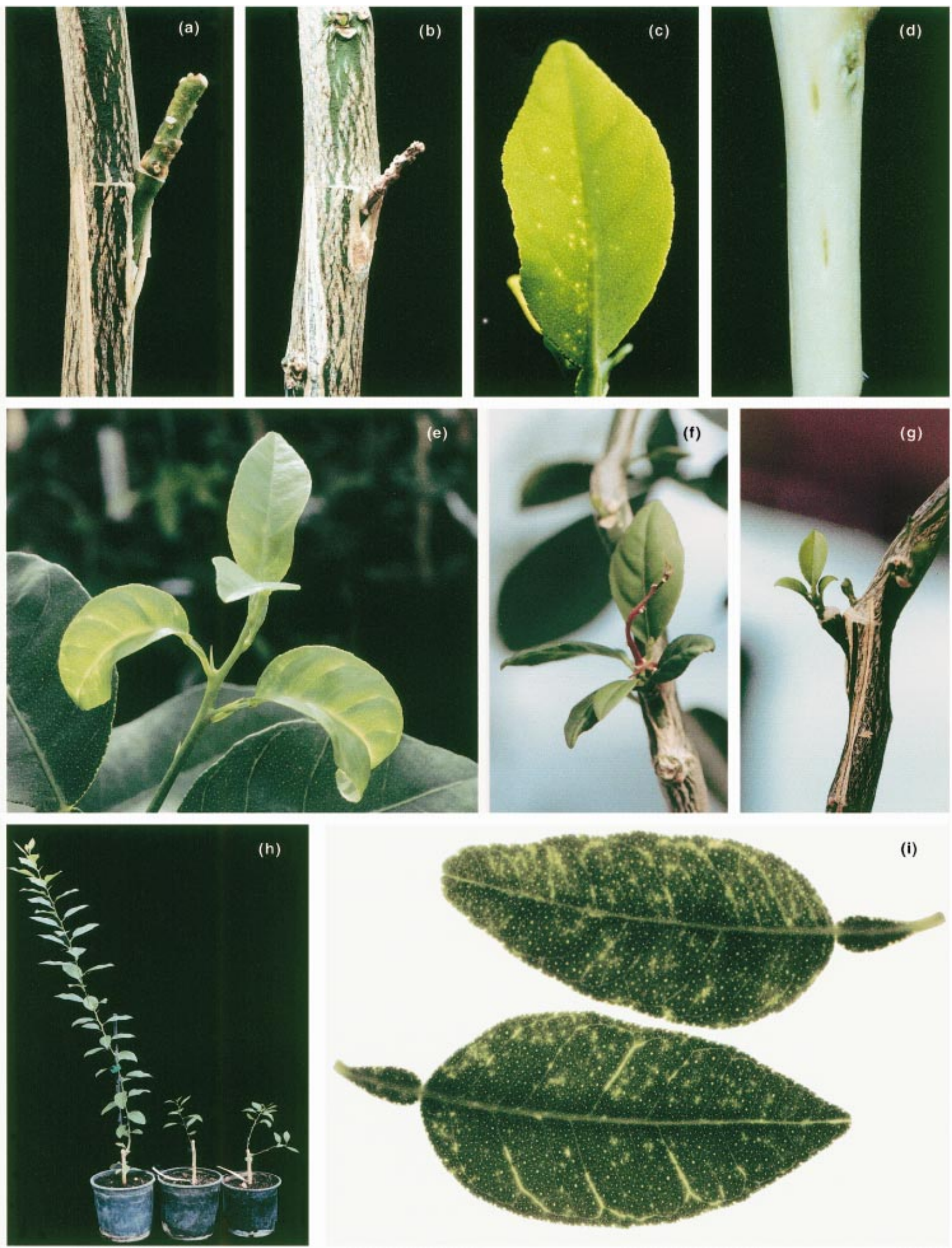

Fig. 3 CTV-like symptoms exhibited by p23-transgenic limes grafted on a vigorous rootstock. (a) and (b) Stem necrosis and subsequent death of young shoots, respectively. (c) Chlorotic pinpoints in a young leaf. (d) Stem pitting. (e) Leaf epinasty. (f) Apical necrosis. (g) Growth interruption. (h) A non-inoculated non-transgenic plant (left), a non-inoculated transgenic plant expressing the p23 protein (middle), and a non-transgenic plant inoculated with a severe CTV isolate (right); the latter two are clearly stunted. (i) Leaves from a non-transgenic plant inoculated with a severe CTV isolate (top) and from a non-inoculated transgenic plant expressing the p23 protein (bottom). 

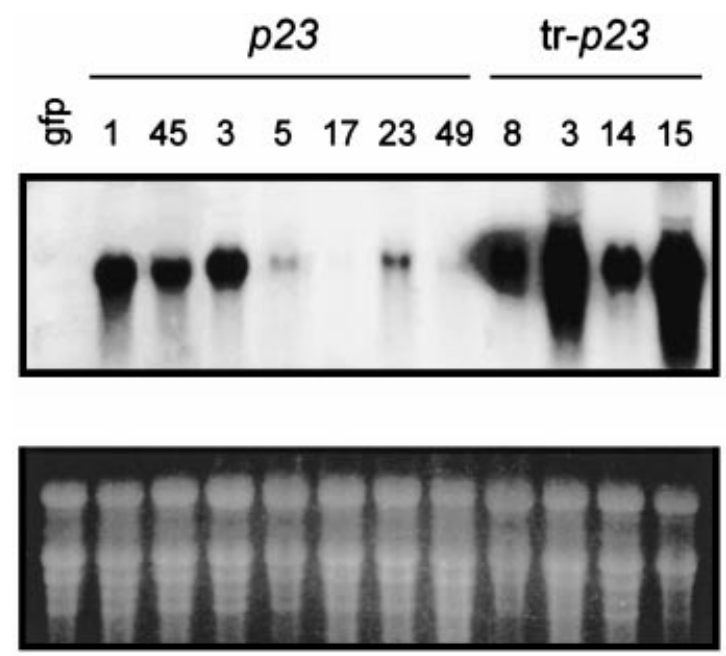

Fig. 4 Steady state accumulation of wild-type and truncated CTV p23 transcripts in transgenic lime plants as revealed by Northern-blot hybridization. (a) Total RNA extracted from transgenic plants was separated by electrophoresis on a formaldehyde-containing agarose gel, transferred to a nylon membrane, and hybridized with a $p 23$-specific DNA probe. sgfp refers to a transgenic line carrying only the $\mathrm{pBin} 19$-sgfp vector, and numbers indicate the corresponding transgenic lines carrying the wild-type (p23) or the truncated (tr-p23) p23 constructs. (b) Ethidium bromide staining of the same gel showing that equivalent amounts of RNA were loaded in the different lanes. wild-type p23-transgenic plants showing CTV-like symptoms (Fig. 4, upper panel). The hybridization signals reflected the levels of $p 23$ or tr-p23 transcripts, because all lanes were loaded with similar amounts of RNA (Fig. 4, lower panel). These results demonstrated that expression of the p23 protein, rather than that of the p23 transcript incited the CTV-like symptoms in the transgenic Mexican lime.

\section{Intensity of CTV-like symptoms parallels the expression level of the p23 transgene}

To analyse the accumulation of $p 23$ transcript in transgenic plants, the RNA fraction insoluble in $2 \mathrm{~m} \mathrm{LiCl} \mathrm{was} \mathrm{subjected} \mathrm{to} \mathrm{a} \mathrm{Northern-}$ blot analysis. The $p 23$-specific probe hybridized with a transcript of approximately $1 \mathrm{~kb}$ in $p 23$-transgenic plants, that was absent in RNA extracts from the transgenic controls carrying only the vector (Fig. 4, upper panel). Presence of the p23 transcript in transgenic plants was therefore associated with the expression of CTV-like symptoms and, moreover, the intensity of these symptoms was directly correlated with the accumulation level of the transcript in young (Fig. 4) and adult leaves (data not shown).

The expression of the p23 protein in each transgenic line was examined by Western-blot analysis. Most $p 23$-transgenic plants showed detectable amounts of the $\mathrm{p} 23$ protein, and its accumulation level also paralleled the intensity of the CTV-like symptoms (Fig. 5).
Fig. 5 Relationship between the steady state accumulation of the CTV p23 protein in transgenic limes, as revealed by Western-blot analysis, and symptom expression in leaves. (a) Total protein extracted from transgenic plants was separated by electrophoresis on an SDS-polyacrylamide gel, transferred to a nitrocellulose membrane, and probed with a CTV p23 antiserum. sgfp refers to a transgenic line carrying only the pBin19-sgfp vector, and numbers indicate the corresponding transgenic lines carrying the wild-type ( $p 23$ ) or the truncated (tr-p23) p23 constructs. CTV refers to a non-transgenic lime infected by the virus. (b) Symptoms observed in transgenic lines carrying the wild-type (p23) or the truncated (tr-p23) p23 constructs, and in a non-transformed lime inoculated with CTV.
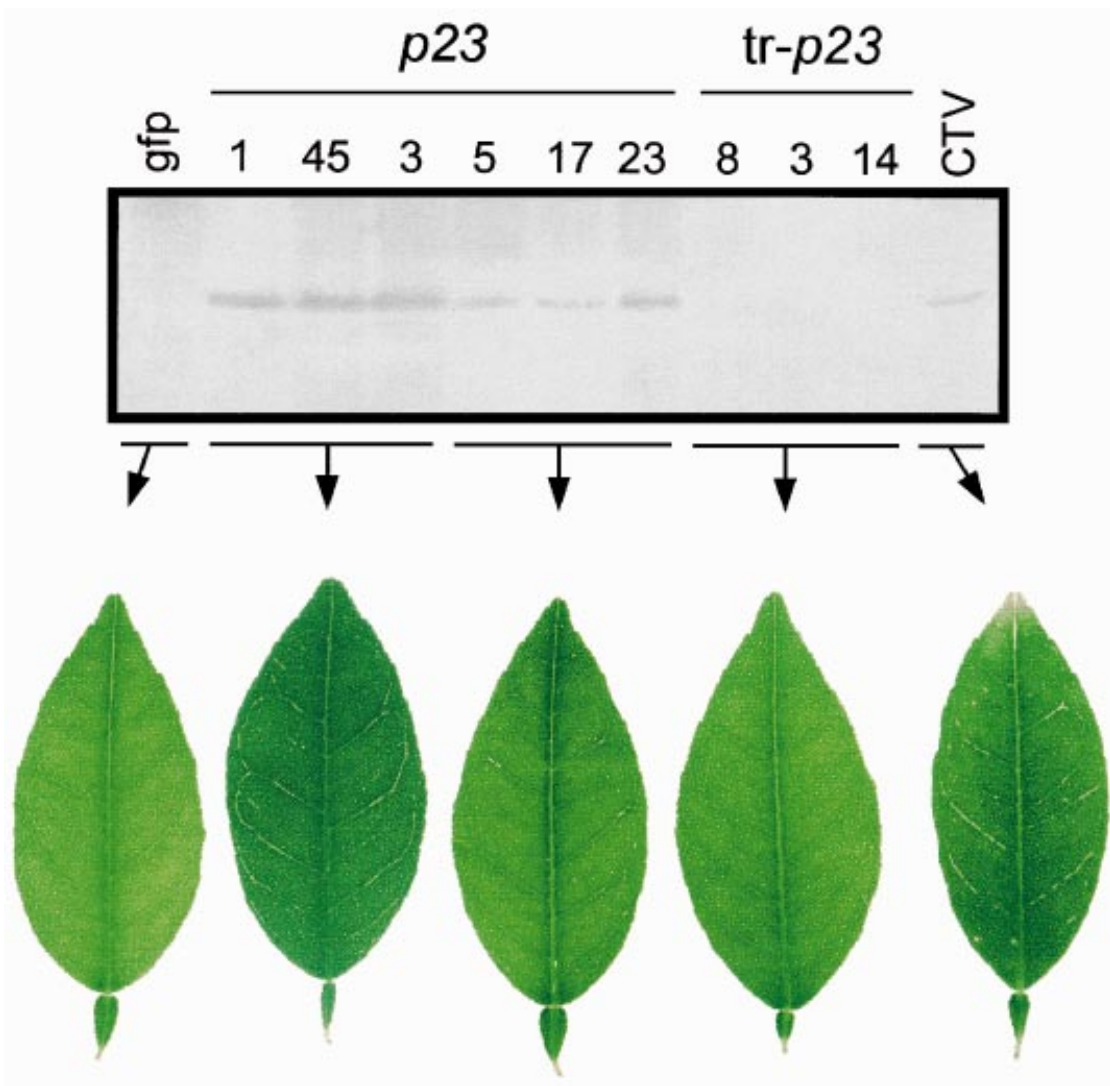
For example, lines 1, 3 and 45 displayed very prominent CTV-like symptoms and accumulated high levels of p23, whereas lines 5 , 17 and 23 exhibited mild symptoms and had low to moderate levels of p23 (Fig. 5). The Western-blot signals were a direct reflection of the levels of $p 23$, because all lanes were loaded with similar amounts of protein (data not shown). These results strongly suggest that expression of the CTV p23 gene in transgenic Mexican lime causes an onset of symptoms similar to those produced by CTV in this host. Transgenic plants generally accumulated higher p23 levels than non-transformed controls infected with a severe CTV isolate (Fig. 5), and similar observations were made when the experiments were repeated using tissues of different ages (data not shown). These results provide an explanation for the early and intense CTV-like symptoms that are observed in most transformants when compared with nontransgenic CTV-inoculated plants.

\section{DISCUSSION}

CTV has the largest undivided genome among plant RNA viruses. The fragility of the virions and the restricted number of tissues infected have made it difficult to study the molecular basis of CTV pathogenesis. More specifically, symptom determinants of CTV isolates that may widely differ in pathogenicity and of other closteroviruses are presently unknown. Although an infectious CTV-CDNA clone has recently been developed (Satyanarayana et al., 1999), little is known about the function of most products potentially encoded by the ORFs of the CTV genome. Among these products, those corresponding to the $p 33, p 13, p 18$ and $p 23$ genes located in the $3^{\prime}$ portion of CTV RNA, have no homologues in other closterovirus genomes. The p23 protein is an RNA-binding protein (López et al., 2000) and contains a motif that is rich in cysteine and histidine residues. This motif is also conserved in nucleic acid-binding proteins encoded by 3'-proximal genes in members of the genera Hordei-, Furo-, Tobra- and Carlaviruses (Morozov et al., 1989; Koonin et al., 1991). On this basis, a regulatory role of p23 in CTV gene expression has been suggested (Dolja et al., 1994; López et al., 1998, 2000).

Here, we have generated transgenic lime plants carrying the p23 transgene under the control of the CaMV 35 S promoter. Constitutive expression of the p23 protein was sufficient to induce phenotypic aberrations resembling the symptoms produced by CTV in non-transgenic plants. The ability of p23 to induce CTV-like symptoms in the Mexican lime, the recommended indicator for CTV (Roistacher, 1991), in the absence of CTV infection demonstrates that p23 is likely to play a key role in CTV pathogenesis. The observation that transgenic plants containing the $p 23$ gene were asymptomatic during the in vitro culture stage is not surprising considering that infected young shoots grown in vitro do not usually express CTV symptoms (R. Ghorbel, unpublished data).

The possibility that the alterations observed in p23-transgenic plants were due to a deleterious effect derived from the in vitro culture process can be discarded because control lime plants transformed with the vector expressing only the marker genes or a modified truncated version of p23 were visually normal. Therefore, expression of the native $\mathrm{p} 23$ protein appears to be the cause of the observed CTV-like symptoms. Moreover, transgenic Mexican limes expressing high levels of the CTV coat protein p25 did not induce such symptoms (Domínguez et al., 2000), indicating that not all CTV proteins are capable of eliciting aberrant phenotypic effects.

CTV-like symptoms displayed by the transgenic plants expressing p23 were generally more intense than those induced by most CTV isolates in non-transgenic limes, as illustrated in the case of vein clearing (Fig. 3i). Interestingly, the amount of p23 protein in transgenic plants was higher than that in CTV-infected plants. This difference in the accumulation of p23 most likely results from the action of the strong CaMV 355 promoter. In spite of having a preference for cells of the vascular system, the $35 \mathrm{~S}$ promoter also expresses p23 constitutively in most other tissues and not just in the phloem, as is the case in non-transgenic plants infected by CTV. Constitutive expression of p23 in transgenic plants would also explain the appearance of prominent chlorotic pinpoints in interveinal leaf tissue (Fig. $3 \mathrm{c}$ ), an alteration that is not usually observed in non-transgenic CTV-infected limes. Finally, over-expression of p23 may incite the most severe phenotypic effects, including the stem necrosis and collapse that is observed in some transgenic lines (Fig. 3a,b).

It is assumed that in virus-infected plants symptoms are caused by metabolic changes induced by the virus, and that they can be dramatically influenced by mutations affecting small regions in the virus genome. Different viral proteins have been identified as pathogenicity determinants. Illustrative examples are proteins p25 and N encoded by the RNA 3 of beet necrotic yellow vein furovirus (BNYVV), causing yellow and necrotic leaf spots in the experimental host Tetragonia expansa, respectively (Jupin et al., 1992). Other examples of important symptom determinants are the p19 and p22 proteins of tomato bushy stunt tombusvirus (TBSV) (Scholthof et al., 1995), the helper component-proteinase (HC-Pro) of potyviruses (Vance et al., 1995), protein 2b of cucumber mosaic cucumovirus (CMV) (Ding et al., 1995), the $\alpha$ a protein of barley stripe mosaic hordeivirus (BSMV) (Weiland and Edwards, 1996), the 126/183 kDa protein of tobacco mosaic tobamovirus (TMV) (Bao et al., 1996), protein AC2 of the bipartite geminivirus african cassava mosaic virus (ACMV) (Hong et al., 1997), and protein C4 of several monopartite geminiviruses (Rigden et al., 1994; Stanley and Latham, 1992).

Furthermore, in some cases, the expression of a single viral protein in transgenic plants has resulted in phenotypes resembling virus-like symptoms. Thus, the expression of the CaMV caulimovirus gene $\mathrm{VI}$ in transgenic tobacco plants resulted in leaf chlorosis, mosaic and stunting in this non-host species (Baughman 
et al., 1988), but these symptoms were not observed following transformation of CaMV-susceptible host species (Goldberg et al., 1989). Constitutive expression of potato leafroll luteovirus (PRLV) ORF 0 in transgenic potato plants also induced a phenotype resembling that of virus-infected plants, although the translation product of this ORF (p28) was not detected (Van der Wilk et al., 1997). In addition, the constitutive expression of elicitor TMV coat proteins induced a hypersensitive reaction in Nicotiana sy/vestris (Culver and Dawson, 1991). Similar observations have been reported in transgenic plants expressing the cell-to-cell movement protein (BC1 or BL1) of certain bipartite geminiviruses as squash leaf curl virus (Pascal et al., 1993), tomato mottle virus (Duan et al., 1997), and bean dwarf mosaic virus (BDMV) (Hou et al., 2000), but, again, these plants were not natural hosts of the corresponding viruses. The same phenomenon has also been observed in transgenic tobacco and tomato plants, and Nicotiana benthamiana plants, expressing the $\mathrm{C} 4$ protein of the monopartite geminiviruses tomato leaf curl virus (Krake et al., 1998) and beet curly top virus (Latham et al., 1997), respectively. Accumulation of BC1 and C4 in transgenic plants was related to symptom severity, and for C4 a role in virus-induced cell proliferation was proposed (Latham et al., 1997). Therefore, the same viral protein appears to be involved in pathogenesis and cell-to-cell movement in this virus family.

None of the cases described above deal with proteins from closteroviruses or with proteins from other viruses that affect woody plants. The results presented here show that CTV p23 most likely plays an important role in CTV symptom expression in its natural host Mexican lime. As already indicated, the RNA-binding properties of p23 are similar to those described for some small cysteine-rich proteins of four genera of plant RNA viruses, including p14 of BNYVV and p17 of BSMV, that are involved in the regulation of gene expression and also in cell-to-cell movement (Donald and Jackson, 1994; Gilmer et al., 1992; Hehn et al., 1995; Petty et al., 1994). The cell-to-cell movement protein of the bipartite BDMV geminivirus also binds single- and double-stranded DNA (Rojas et al., 1998), and TBSV p22 has a domain governing cell-to-cell movement and another eliciting a necrotic response in resistant N. edwardsonii plants (Chu et al., 2000). By analogy, CTV p23 may have a role in the cell-to-cell movement of CTV through plasmodesmata, considering that this process is mediated by at least five proteins in BYV, another closterovirus (Alzhanova et al., 2000; Peremyslov et al., 1999). On the other hand, involvement of p23 in an early step of CTV RNA replication and transcription has been suggested on the basis of the temporal accumulation pattern of its sgRNA (Navas-Castillo et al., 1997). Furthermore, p23 appears to be involved in the regulation of the $(+) /(-)$ ratio of CTV RNA strands (W.O. Dawson, personal communication).

In summary, we have shown that CTV p23 protein is responsible for the production of CTV-like symptoms in transgenic Mexican lime plants, and that there is a specific association between p23 accumulation and exacerbation of these symptoms. This is the first case in which a protein from a woody plant virus has been identified as being directly involved in pathogenesis in its natural host. Our finding also delimits a small region of the large CTV genome for future searches of specific pathogenic determinants.

\section{EXPERIMENTAL PROCEDURES}

\section{Cloning of CTV p23 gene and of its truncated version}

In order to fuse the CTV $p 23$ gene to the binary vector pBin19sgfp (Chiu et al., 1996), the fragment between positions 18394 and 19023 of the genomic sequence of CTV isolate T36 (GENBANK accession no. U16304) (Karasev et al., 1995; Pappu et al., 1994), was PCR-amplified from plasmid p12AX1 containing a complete CDNA copy of this sequence (J. Navas-Castillo and S. Gowda, unpublished data). PCR amplification was performed with $P f u$ DNA polymerase (Promega) using the sense and antisense primers RF-167 (5'-CT TGGATCCATGGATAATACTAGCGG-3') and RF-168 (5'-CT TGGATCCTCAGATGAAGTGGTGT TC-3'), respectively, containing a BamHI restriction site (underlined) to facilitate cloning. The $p 23$ start and stop codons are in bold in the sense and antisense primers, respectively. After BamHI digestion, the PCR-amplified fragment was inserted between the CaMV 355 promoter and the nopaline synthase terminator (nos-ter) by ligation in BamHI-digested pMOG180, generating the intermediate plasmid pMOG-p23. This plasmid was also used to create a truncated $p 23$ construct by interrupting the p23 ORF. For this purpose, the plasmid was PCR-amplified with Pfu DNA polymerase and the pair of divergent primers of opposite polarity RF-267 (5'-GAAAGTTTGTCCGCTAGTATTATCCAT-3') and RF-268 (5'-TTTCTGTGAACCTTTCTGACGAAAGCAAC-3'), complementary and homologous to positions $18394-18420$ and 18 423-18 450 of the T36 sequence, respectively, to yield pMOGtr-p23 after ligation. In this plasmid, deletion of nucleotide residues 28 and 29 of the p23 ORF causes a frameshift leading to a stop codon immediately after position 42 . This mutant version of $p 230 R F$ expresses a peptide of 14 amino acid residues, of which only the first nine are the same as in the wild-type $p 23$. The resulting pMOG-p23 and pMOG-tr-p23 plasmids were digested with HindIII and the fragments containing the $p 23$ and tr-p23 cassettes were inserted into the unique Hindlll site of the binary vector pBin19-sgfp between the cassettes nos-pro/nptll/nos-ter and 35S-pro/sgfp/nos-ter, respectively. The vector pBin19-sgfp and its two derivatives containing the $p 23$ and tr-p23 cassettes were electroporated into the disarmed $A$. tumefaciens strain EHA105.

\section{Plant transformation}

Internodal stem segments of Mexican lime were transformed by cocultivation with $A$. tumefaciens as previously described (Ghorbel et al., 1999). Selection of transformants was performed on a culture 
medium containing kanamycin $(100 \mathrm{mg} / \mathrm{L})$ and the regenerated shoots were examined under a stereomicroscope equipped with a Leica@ fluorescence module. Those shoots exhibiting bright green fluorescence were excised and grafted in vitro on seedlings of Carrizo citrange as previously described (Peña and Navarro, 1999). After 3-4 weeks, scions had on developed several leaves and one was used to detect $p 23$ and tr-p23 transgenes by PCR analysis with primers RF-167 and RF-168. PCR products of the size expected for $p 23$ and tr-p23 were detected by electrophoresis in a $2 \%$ agarose gel. Transgenic plantlets were then side-grafted on vigorous 5-month-old seedling of Rough lemon and grown in a temperature-controlled greenhouse for transgenic plants with $24-27 / 18-20^{\circ} \mathrm{C}$ day/night temperature, and a relative humidity between 60 and $80 \%$. Plants were grown in individual $2.5 \mathrm{~L}$ pots containing a mixture of $55 \%$ Sphagnum peat and $45 \%$ siliceous sand, and were fertilized weekly.

\section{Southern and Northern blot hybridization}

Southern blot assays were performed to analyse the integrity of the $p 23$ and tr-p23 expression cassettes and to estimate the number of copies of the chimeric genes in the transgenic lime plants. DNA was extracted from the leaves according to the method of Dellaporta et al. (1983) and an aliquot $(20 \mu \mathrm{g})$ was digested with Hindlll, which excises the expression cassette, or with EcoRI, which cuts the T-DNA once near the left border (Fig. 1). After electrophoresis in $1 \%$ agarose gels, the DNA was blotted on to a nylon membrane, fixed by UV irradiation and probed with a digoxigenin-labelled fragment of the $p 23$ coding region that had been prepared by PCR according to manufacturer's instructions (Boehringer-Mannheim).

For the Northern blot analysis, total leaf RNA from transgenic plants was extracted with buffer-saturated phenol and then fractionated with $2 \mathrm{M} \mathrm{LiCl}$ (Carpenter and Simon, 1998). Aliquots $(20 \mu \mathrm{g})$ of the insoluble RNAs were electrophoresed in $1 \%$ agarose gels containing formaldehyde, blotted on to a nylon membrane and fixed by UV irradiation. Prehybridization, hybridization and washing of the membranes were performed as previously reported (Flores, 1986), except that the hybridization was at $50^{\circ} \mathrm{C}$ in the presence of $50 \%$ formamide. The radioactive $p 23$-specific CDNA probe was prepared with 'Ready-To-Go' DNA labelling beads (Amersham Pharmacia Biotech Inc.), using $50 \mathrm{ng}$ of template.

\section{Antiserum production and Western blot analysis}

The CTV p23 gene from T36 isolate, fused to the maltose binding protein, was expressed in bacterial cells and purified as previously described (López et al., 2000). The purified fusion protein (75 $\mu \mathrm{g}$ ) in $500 \mu \mathrm{L}$ of $50 \mathrm{~mm}$ Tris- $\mathrm{HCl}$, pH 8.0, was emulsified in the presence of an equal volume of Freund's complete adjuvant and injected intradermally to a rabbit. Immunizations were repeated three times at 2-week intervals but using incomplete adjuvant. The rabbit was bled 2 weeks after the last immunization and the serum was recovered by centrifugation, titrated and kept at $-20^{\circ} \mathrm{C}$.

Accumulation of p23 protein in transgenic plants was tested by Western blot analysis. Leaf tissues were ground with liquid nitrogen and resuspended in three volumes of $100 \mathrm{~mm}$ Tris- $\mathrm{HCl}$, $\mathrm{pH} 6.8$, containing $0.3 \% \beta$-mercaptoethanol and $1 \mathrm{~mm}$ phenylmethyl-sulphonyl fluoride. After addition of an equal volume of 2 $\times$ Laemmli buffer and denaturation at $95^{\circ} \mathrm{C}$ for $10 \mathrm{~min}$ (Laemmli, 1970), extracts were clarified by centrifugation for $10 \mathrm{~min}$. Aliquots $(20 \mu \mathrm{L})$ were electrophoresed in 15\% SDS-polyacrylamide gels and electroblotted on to nitrocellulose membranes. Proteins were probed with a $1: 7500$ dilution of the antiserum raised against CTV p23 protein, and binding of the antibody was detected with goat anti-rabbit lgG conjugated with alkaline phosphatase (Promega) and visualized with nitroblue tetrazolium and 5-bromo-4-chloro3-indolyl phosphate.

\section{ACKNOWLEDGEMENTS}

We thank J. A. Pina and J. Juárez for their excellent technical assistance. This research was supported by grants from the Instituto Nacional de Investigaciones Agrarias (SC97-102 and SC97-098), and from CICYT-European Union (1FD97-0822). R. Ghorbel was the recipient of a fellowship from the Agencia Española de Cooperación Internacional.

\section{REFERENCES}

Alzhanova, D.V., Hagiwara, Y., Peremyslov, V.V. and Dolja, V.V. (2000) Genetic analysis of the cell-to-cell movement of beet yellow closterovirus. Virology, 268, 192-200.

Bao, Y., Carter, S.A. and Nelson, R.S. (1996) The 126- and 183-kilodalton proteins of tobacco mosaic virus, and not their common nucleotide sequence, control mosaic symptom formation in tobacco. J. Virol. 70, 6378-6383.

Bar-Joseph, M., Marcus, R. and Lee, R.F. (1989) The continuous challenge of citrus tristeza virus control. Annu. Rev. Phytopathol. 27, 291-316.

Baughman, G.A., Jacobs, J.D. and Howell, S.H. (1988) Cauliflower mosaic virus gene $\mathrm{VI}$ produces a symptomatic phenotype in transgenic tobacco plants. Proc. Natl Acad. Sci. USA, 85, 733-737.

Baulcombe, D.C. (1996) Mechanisms of pathogen-derived resistance to viruses in transgenic plant. Plant Cell, 8, 1833-1844.

Carpenter, C.D. and Simon, A.E. (1998) Preparation of RNA. Meth. Mol. Biol. 82, 85-89.

Chiu, W., Niwa, Y., Zeng, W. and Hirano, T. (1996) Engineered GFP as a vital reporter in plants. Curr. Biol. 6, 325-330.

Chu, M., Desvoyes, B., Turina, M., Noad, R. and Scholthof, H.B. (2000) Genetic dissection of tomato bushy stunt virus p19-protein-mediated host-dependent symptom induction and systemic invasion. Virology, 266, 79-87.

Culver, J.N. and Dawson, W.O. (1991) Tobacco mosaic virus elicitor coat protein genes produce a hypersensitive phenotype in transgenic Nicotiana sylvestris plants. Mol. Plant-Microbe Interact. 4, 458-463. 
Dellaporta, S.L., Wood, J. and Hicks, J.B. (1983) A plant DNA minipreparation: version II. Plant Mol. Biol. Rep. 4, 19-21.

Ding, S.W., Li, W.X. and Symons, R.H. (1995) A novel occurring hybrid gene encoded by a plant RNA virus facilitates long distance virus movement. EMBO J. 14, 5762-5772.

Dolja, V.V., Karasev, A.V. and Koonin, E.V. (1994) Molecular biology and evolution of closterovirus: sophisticated build-up of large RNA genomes. Annu. Rev. Phytopathol. 32, 261-285.

Domínguez, A., Guerri, J., Cambra, M., Navarro, L., Moreno, P. and Peña, L. (2000) Efficient production of citrus transgenic plants expressing the coat protein gene of Citrus Tristeza Virus. Plant Cell Rep. 19, 427-433.

Donald, R.G. and Jackson, A.0. (1994) The barley stripe mosaic virus gamma $b$ gene encodes a multifunctional cysteine-rich protein that affects pathogenesis. Plant Cell, 6, 1593-1606.

Duan, Y.P., Powell, C.A., Purcifull, D.E., Broglio, P. and Hiebert, E. (1997) Phenotypic variation in transgenic tobacco expressing mutated geminivirus movement/pathogenicity (BC1) proteins. Mol. PlantMicrobe Interact. 10, 1065-1074.

Febres, V.J., Ashoulin, L., Mawassi, M., Frank, A., Bar-Joseph, M., Manjunath, K.L., Lee, R.F. and Niblett, C.L. (1996) The p27 protein is present at one end of citrus tristeza virus particles. Phytopathology, 86, 1331-1335.

Flores, R. (1986) Detection of citrus exocortis viroid in crude extracts by dotblot hybridization: conditions for reducing spurious hybridization results and for enhancing the sensitivity of the technique. J. Virol. Meth, 13, 161-169.

Ghorbel, R., Juárez, J., Navarro, L. and Peña, L. (1999) Green fluorescent protein as a screenable marker to increase the efficiency of generating transgenic woody fruit plants. Theor. Appl. Genet. 99, 350-358.

Gilmer, D., Bouzoubaa, S., Hehn, A., Guilley, H., Richards, K. and Jonard, G. (1992) Efficient cell-to-cell movement of beet necrotic yellow vein virus requires 3' proximal genes located on RNA 2. Virology, 189, 40-47.

Goldberg, K., Kiernan, J., Schoelz, J.E. and Shephard, R.J. (1989) Transgenic host response to gene VI of two caulimoviruses. In: Viral Genes and Plant Pathogenesis (Pirone, T.P. and Shaw, J.G., eds). New York: Springer Verlag, pp. 58-66.

Hehn, A., Bouzoubaa, S., Bate, N., Twell, D., Marbach, J., Richards, K., Guilley, H. and Jonard, G. (1995) The small cysteine-rich protein P14 of beet necrotic yellow vein virus regulates accumulation of RNA 2 in cis and coat protein in trans. Virology, 210, 73-81.

Hilf, M.E., Karasev, A.V., Pappu, H.R., Gumpf, D.J., Niblett, C.L. and Garnsey, S.M. (1995) Characterization of citrus tristeza virus subgenomic RNAs in infected tissue. Virology, 208, 576-582.

Hong, Y., Saunders, K. and Stanley, J. (1997) Transactivation of dianthin expression by African cassava mosaic virus AC2. Virology, 228, 383-387.

Hou, Y.M., Sanders, R., Ursin, V.M. and Gilbertson, R.L. (2000) Transgenic plants expressing geminivirus movement proteins: abnormal phenotypes and delayed infection by tomato mottle virus in transgenic tomatoes expressing the bean dwarf mosaic virus BV1 or BC1 proteins. Mol. Plant-Microbe Interact. 13, 297-308.

Jupin, I., Guilley, H., Richards, K.E. and Jonard, G. (1992) Two proteins encoded by beet necrotic yellow vein virus RNA 3 influence symptom phenotype on leaves. EMBO J. 11, 479-488.

Karasev, A.V., Boyko, V.P., Gowda, S., Nikolaeva, O.V., Hilf, M.E., Koonin, E.V., Niblett, C.L., Cline, K., Gumpf, D.J., Lee, R.F., Garnsey, S.M. and Dawson, W.O. (1995) Complete sequence of the citrus tristeza virus RNA genome. Virology, 208, 511-520.

Koonin, E.V., Boyko, V.P. and Dolja, V.V. (1991) Small cysteine-rich proteins of different groups of plant RNA viruses are related to different families of nucleic acid-binding proteins. Virology, 81, 395-339.

Krake, L.R., Rezaian, M.A. and Dry, I.B. (1998) Expression of the tomato leaf curl Geminivirus C4 gene produces virus-like symptoms in transgenic plants. Mol. Plant-Microbe Interact. 11, 413-417.

Laemmli U.K. (1970) Cleavage of structural proteins during the assembly of the head of bacteriophage T4. Nature, 227, 680-685.

Latham, J.R., Saunders, K., Pinner, M.S. and Stanley, J. (1997) Induction of plant cell division by beet curly top virus gene C4. Plant J. 11, 1273-1283.

López, C., Ayllon, M.A., Navas, J., Guerri, J., Moreno, P. and Flores, R. (1998) Molecular variability of the $5^{\prime}$ and $3^{\prime}$ terminal regions of the citrus tristeza virus RNA. Phytopathology 88, 685-691.

López, C., Navas-Castillo, J., Gowda, S., Moreno, P. and Flores, R. (2000) The $23 \mathrm{kDa}$ protein coded by the 3'-terminal gene of citrus tristeza virus is an RNA-binding protein. Virology, 269, 462-470.

Mawassi, M., Mietkiewska, E., Gofman, R., Yang, G. and Bar-Joseph, M. (1996) Unusual sequence relationships between two isolates of citrus tristeza virus. J. Gen. Virol. 77, 2359-2364.

Morozov, S.Yu, Dolja, V.V. and Atabekov, J.G. (1989) Probable reassortment of genomic elements among elongated RNA-containing plant viruses. J. Mol. Evol. 29, 52-62.

Navas-Castillo, J., Albiach-Marti, M.R., Gowda, S., Hilf, M.E., Garnsey, S.M. and Dawson, W.O. (1997) Kinetics of accumulation of citrus tristeza virus RNAs. Virology, 228, 92-97.

Pappu, S.S., Febres, V.V., Pappu, H.R., Lee, R.F. and Niblett, C.L. (1997) Characterization of the 3' proximal gene of the citrus tristeza closterovirus genome. Virus Res. 47, 51-57.

Pappu, H.R., Karasev, A.V., Anderson, E.J., Pappu, S.S., Hilf, M.E., Febres, V.J., Eckloff, R.M.G., Mccaffery, M., Boyko, V., Gowda, S., Dolja, V.V., Koonin, E.V., Gumpf, D.J., Cline, K.C., Garnsey, S.M., Dawson, W.O., Lee, R.F. and Niblett, C.L. (1994) Nucleotide sequence and organization of eight $3^{\prime}$ open reading frames of the citrus tristeza closterovirus genome. Virology, 199, 35-46.

Pascal, E., Goodlove, P.E., Wu, L.C. and Lazarowitz, S.G. (1993) Transgenic tobacco plants expressing the geminivirus BL1 protein exhibit symptoms of viral disease. Plant Cell, 5, 795-807.

Peña, L. and Navarro, L. (1999) Transgenic citrus. In Biotechnology in Agriculture and Forestry, Vol. 44, Transgenic Trees (Y.P.S. Bajaj, ed.). Berlin/Heidelberg: Springer-Verlag, pp. 39-54.

Peremyslov, V.V., Hagiwara, Y. and Dolja, V.V. (1999) HSP70 homolog functions in cell-to-cell movement of a plant virus. Proc. Natl Acad. Sci. USA, 96, 14 771-14 776.

Petty, I.T.D., Donald, R.G. and Jackson, A.O. (1994) Multiple genetic determinants of barley stripe mosaic virus influence lesion phenotype on Chenopodium amaranticolor. Virology, 198, 218-226.

Rigden, J.E., Krake, L.R., Rezaian, M.A. and Dry, I.B. (1994) ORF C4 of tomato leaf curl geminivirus is a determinant of symptom severity. Virology, 204, 847-850.

Roistacher, C.N. (1991) Graft-transmissible Diseases of Citrus. Handbook for Detection Diagnosis. Rome: Food and Agriculture Organization, p. 286.

Rojas, M.R., Noueiry, A.O., Lucas, W.J. and Gilbertson, R.L. (1998) Bean dwarf mosaic geminivirus movement proteins recognize DNA in a form- and size-specific manner. Cell, 95, 105-113.

Sanford, J.C. and Johnston, S.A. (1985) The concept of parasite-derived resistance: Deriving resistance genes from the parasite's own genome. J. Theor. Biol. 113, 395-405.

Satyanarayana, T., Gowda, S., Boyko, V.P., Albiach-Marti, M.R., Mawassi, M., Navas-Castillo, J., Karasev, A.V., Dolja, V., Hilf, M.E., 
Lewandowski, D.J., Moreno, P., Bar-Joseph, M., Garnsey, S.M. and Dawson, W.O. (1999) An engineered closterovirus RNA replicon and analysis of heterologous terminal sequences for replication. Proc. Natl Acad. Sci. USA, 96, 7433-7438.

Scholthof, H.B., Scholthof, K.B. and Jackson, A.O. (1995) Identification of tomato bushy stunt virus host-specific symptom determinants by expression of individual genes from a potato virus X vector. Plant Cell, 7, 1157-1172.

Sekiya, M.E., Lawrence, S.D., Mccaffery, M. and Cline, K. (1991) Molecular cloning and nucleotide sequencing of the coat protein gene of citrus tristeza virus. J. Gen. Virol. 72, 1013-1020.

Stanley, J. and Latham, J.R. (1992) A symptom variant of beet curly top geminivirus produced by mutation of open reading frame C4. Virology, 190, 506-509.

Van der Wilk, F., Houterman, P., Molthoff, J., Hans, F., Dekker, B., van den Heuvel, J., Huttinga, H. and Goldbach, R. (1997) Expression of the potato leafroll virus ORFO induces viral-disease-like symptoms in transgenic potato plants. Mol. Plant-Microbe Interact. 10, 153-159.
Vance, V.B., Berger, P.H., Carrington, J.C., Hunt, A.G. and Shi, X.M. (1995) 5' proximal potyviral sequences mediate potato virus $X /$ potyviral synergistic disease in transgenic tobacco. Virology, 206, 583-590.

Vela, C., Cambra, M., Cortes, E., Moreno, P., Miguet, S.G., Pérez de San Román, C. and Sanz, A. (1986) Production and characterisation of monoclonal antibodies specific for citrus tristeza virus and their use for diagnostic. J. Gen. Virol. 67, 91-96.

Vives, M.C., Rubio, L., López, C., Navas-Castillo, J., Albiach-Martì.M.R., Dawson, W.O., Guerri, J., Flores, R. and Moreno, P. (1999) The complete genome sequence of the major component of a mild citrus tristeza virus isolate. J. Gen. Virol. 80, 811-816.

Weiland, J.J. and Edwards, M.C. (1996) A single nucleotide substitution in the $\alpha$ a gene confers oat pathogenicity to barley stripe mosaic virus strain ND18. Mol. Plant-Microbe Interact. 9, 62-67.

Yang, Z.N., Mathews, D.H., Dodds, J.A. and Mirkov, T.E. (1999) Molecular characterization of an isolate of citrus tristeza virus that causes severe symptoms in sweet orange. Virus Genes, 19, 131-142. 